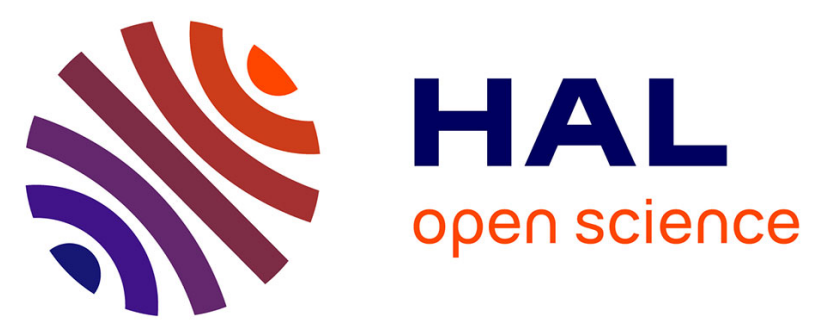

\title{
The Gene Encoding the Mouse Homologue of the Human Osteoclast-Specific 116-kDa V-ATPase Subunit Bears a Deletion in Osteosclerotic (oc/oc) Mutants
} J.-C Scimeca, A. Franchi, C. Trojani, Hugues Parrinello, J Grosgeorge, Cédric Robert Robert, O. Jaillon, C. Poirier, P Gaudray, G F Carle

\section{To cite this version:}

J.-C Scimeca, A. Franchi, C. Trojani, Hugues Parrinello, J Grosgeorge, et al.. The Gene Encoding the Mouse Homologue of the Human Osteoclast-Specific 116-kDa V-ATPase Subunit Bears a Deletion in Osteosclerotic (oc/oc) Mutants. BONE, 2000, 10.1016/S8756-3282(99)00278-1 . hal-02117516

\author{
HAL Id: hal-02117516 \\ https://hal.science/hal-02117516
}

Submitted on 2 May 2019

HAL is a multi-disciplinary open access archive for the deposit and dissemination of scientific research documents, whether they are published or not. The documents may come from teaching and research institutions in France or abroad, or from public or private research centers.
L'archive ouverte pluridisciplinaire $\mathbf{H A L}$, est destinée au dépôt et à la diffusion de documents scientifiques de niveau recherche, publiés ou non, émanant des établissements d'enseignement et de recherche français ou étrangers, des laboratoires publics ou privés. 


\title{
The Gene Encoding the Mouse Homologue of the Human Osteoclast-Specific 116-kDa V-ATPase Subunit Bears a Deletion in Osteosclerotic (oc/oc) Mutants
}

\author{
J.-C. SCIMECA, ${ }^{1}$ A. FRANCHI, ${ }^{1}$ C. TROJANI, ${ }^{1}$ H. PARRINELlO,${ }^{1}$ J. GROSGEORGE, ${ }^{1}$ C. ROBERT, ${ }^{2}$ \\ O. JAILLON, ${ }^{2}$ C. POIRIER,${ }^{3}$ P. GAUDRAY, ${ }^{1}$ and G. F. CARLE ${ }^{1}$ \\ ${ }^{1}$ Instabilité et Altérations des Génomes, UMR6549 CNRS/UNSA, Faculté de Médecine de l'Université de Nice-Sophia Antipolis, Nice, France \\ ${ }^{2}$ Génoscope, Centre National de Séquençage, Evry, France \\ ${ }^{3}$ Unité de Génétique des Mammifères, Institut Pasteur, Paris, France
}

\begin{abstract}
Osteosclerosis $(o c)$ is an autosomal recessive lethal mutation that impairs bone resorption by osteoclasts, and induces a general increase of bone density in affected mice. Genetic mapping of the $o c$ mutation was used as a backbone in a positional cloning approach in the pericentromeric region of mouse chromosome 19. Perfect cosegregation of the osteopetrotic phenotype with polymorphic markers enabled the construction of a sequence-ready bacterial artificial chromosome (BAC) contig of this region. Genomic sequencing of a $200-\mathrm{kb}$ area revealed the presence of the mouse homologue to the human gene encoding the osteoclast-specific 116-kDa subunit of the vacuolar proton pump. This gene was located recently on human 11q13, a genomic region conserved with proximal mouse chromosome 19 . Sequencing of the $5^{\prime}$ end of the gene in $o c / o c$ mice showed a 1.6-kb deletion, including the translation start site, which impairs genuine transcription of this subunit. The inactivation of this osteoclast-specific vacuolar proton ATPase subunit could be responsible for the lack of this enzyme in the apical membranes of osteoclast cells in $o c / o c$ mice, thereby preventing the resorption function of these cells, which leads to the osteopetrotic phenotype. (Bone 26:207-213; 2000) (C) 2000 by Elsevier Science Inc. All rights reserved.
\end{abstract}

Key Words: Osteopetrosis; oc mutant; V-ATPase; Physical mapping; Mouse chromosome 19.

\section{Introduction}

Osteopetrosis, also known as marble bone disease, is a metabolic bone disorder that is characterized by a general increase of bone density resulting from a defect in osteoclast presence or function. Several genetically inherited forms of the disease have been described in humans. There are four spontaneous osteopetrotic mutations in mice that have been reported: op/op (osteopetrosis), $\mathrm{mi} / \mathrm{mi}$ (microphtalmia), $\mathrm{gl} / \mathrm{gl}$ (grey-lethal), and oc/oc (osteosclerosis). The osteoclast deficiency in op/op mice is due to a mutation in the coding region of the macrophage colony-stimu-

Address for correspondence and reprints: Dr. Georges F. Carle, Instabilité et Altérations des Génomes, UMR6549 CNRS/UNSA, Faculté de Médecine de l'Université de Nice-Sophia Antipolis, 06107 Nice, France. E-mail: carle@unice.fr lating factor gene (M-CSF1), ${ }^{22}$ and a defect in a gene coding for a helix-loop-helix transcription factor is responsible for the microphtalmia phenotype. ${ }^{13}$ Currently, the genes associated with $o c$ or $g l$ mutations have not been identified.

Osteosclerosis $(o c)$ is a mouse osteopetrotic mutation inherited as an autosomal lethal recessive trait that arose spontaneously in 1966 at the Jackson Laboratory in the C57BL/6J-bf strain, ${ }^{5}$ and has been backcrossed over 20 times to the hybrid $\mathrm{C} 57 \mathrm{BL} / 6 \mathrm{Jle} \times \mathrm{C} 3 \mathrm{HeB} / \mathrm{FeJLe}-a / a \mathrm{~F}_{1}$, in order to increase the survival time of the affected $o c / o c$ animals. The oc/oc homozygote mice usually die around 3 weeks of age, and the mutation has been maintained in $o c /+$ heterozygotes, which do not display any particular phenotype. Affected animals (oc/oc) exhibit the characteristic radiologic and histologic features of osteopetrosis, including a generalized increase in skeletal density and absence of marrow cavities easily detected by X-ray radiography (Figure 1).

Oc was originally mapped to mouse chromosome 19 (MMU19) with fairly loose precision by Lane. ${ }^{14}$ In 1985, Marks et al. ${ }^{17}$ gave a better characterization of the phenotype and anchored the mutation in the pericentromeric region of MMU19. However, in this initial genetic mapping effort, the closest phenotypic marker brachymorphic $(\mathrm{bm})$ was located $30 \mathrm{cM}$ telomeric of $o c$, and no close markers were shown to segregate with the osteopetrotic phenotype. We have undertaken a comparative mapping study of a syntenic area of the genome that has been conserved through evolution between human 11q13 and the pericentromeric region of mouse chromosome 19.4,8,21 Many genes involved in inherited human pathologies and localized on 11 13 have an homologous gene present on proximal MMU19 region and vice versa. ${ }^{20}$ This gene conservation between mice and humans has been very helpful in designing new probes to refine the physical map. Moreover, it has been a source of candidate genes for positional cloning in both species. In our attempt to identify candidate genes for $o c$, we were able to exclude the Fos-related antigen 1 gene ( $\mathrm{fra}-1)$, based on its segregation pattern and an allelism test, ${ }^{19}$ as well as a putative transporter gene $($ Roct 1$),{ }^{3}$ based on physical mapping results (data not shown).

The positional cloning approach we followed consisted of four phases: defining the smallest candidate region based on proximal and distal meiotic recombination events, constructing a high-density physical map, sequencing the region of interest, and performing genomic database comparisons. In this report, we 


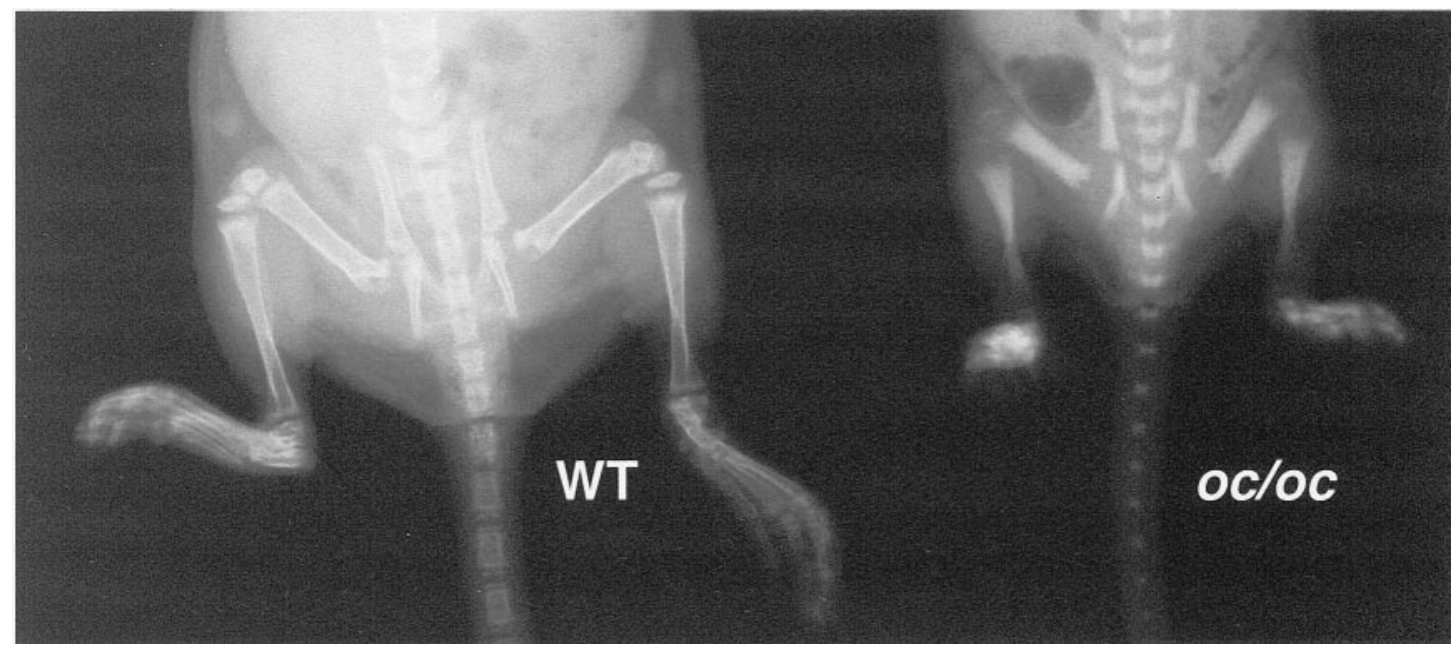

Figure 1. Radiographic images of a 14-day-old normal mouse (wt) and its osteosclerotic littermate (oc/oc). A general increase of bone density and disappearance of bone marrow space can be observed in the mutant.

present evidence showing a 1.6-kb genomic deletion in mouse osteosclerotic mutants $(o c / o c)$ removing the translation start site in the gene homologous to the human OC 116-kDa osteoclastspecific vacuolar proton pump subunit.

\section{Materials and Methods}

\section{Mice}

Two pairs of $(\mathrm{C} 57 \mathrm{BL} / 6 \mathrm{~J} \times \mathrm{C} 3 \mathrm{HheB} / \mathrm{FeJ}) \mathrm{F} 1 o c /+$ mice were initially obtained from the Jackson Laboratory (Bar Harbor, ME) and maintained in our central animal facility in accordance with the general guidelines edicted by the Direction des Services Vétérinaires. Heterozygotes animals $(o c /+)$ were identified 3 weeks after birth by DNA genotyping (tail clipping) with a polymorphic marker (D19Mit68) cosegrating with the mutation. Animals suspected to be homozygous at the oc locus (smaller size than littermate, circling behavior, absence of or delayed incisors eruption) were systematically submitted to radiographic analysis for final phenotyping. Mus spretus mice (SEG imbred strain) were obtained from the Unité de Génétique des Mammifères (Institut Pasteur, Paris).

\section{Yeast Artificial Chromosome (YACs) and Bacterial Artificial Chromosome (BAC) Identification}

We initially identified YACs from the candidate region by screening four different mouse libraries (Princeton Library, MIT/ Whitehead Institute Library, St Mary's Hospital Library, and Imperial Cancer Research Fund (ICRF) Library). The screenings were performed with the help of either the Princeton or Généthon screening facility. BACs were then identified with polymerase chain reaction (PCR)-based screening of pooled libraries (Research Genetics, Huntsville, AL) with various STS from the interval. STS were obtained, mainly from BAC end-sequencing, but also by taking advantage of the conservation between HSA11q13 and the pericentomeric region of MMU19.

\section{BAC DNA Purification and BAC End-Sequencing}

BAC DNAs were prepared using a Nucleobond PC kit from Macherey-Nagel (Hoerdt, France), according to the manufacturer's instructions. BAC end-sequencing reactions were performed with $5 \mu \mathrm{g}$ of template, using the Thermo Sequenase kit (Amersham, Les Ulis, France), and IRD700- or IRD800-labeled SP6 or T7 primers (MWG Biotech, Ebersberg, Germany). Sequencing reaction products were analyzed on a LI-COR Long ReadIR 4200 DNA sequencer (LI-COR Inc., Lincoln, NE)

\section{Polymerase Chain Reaction}

Polymerase chain reaction was performed using primers and annealing temperatures reported in Table 1 . The $25-\mu \mathrm{L}$ reaction volume contained $25 \mathrm{pmol}$ of each primer, 3.13 pmol dNTPs, 1.5 $\mathrm{mmol} / \mathrm{L} \mathrm{MgCl}_{2}$, and $0.5 \mathrm{U}$ of platinium Taq DNA polymerase (Life Technologies, Cergy Pontoise, France). After $2 \mathrm{~min}$ at $95^{\circ} \mathrm{C}, \mathrm{PCR}$ was carried out for 35 cycles with the following steps: $94^{\circ} \mathrm{C}$ for $30 \mathrm{sec}$, annealing temperature for $30 \mathrm{sec}$, and $72^{\circ} \mathrm{C}$ for $30 \mathrm{sec}$. A final extension step at $72^{\circ} \mathrm{C}$ for $10 \mathrm{~min}$ concluded each reaction. Amplification was performed in a PTC-100 thermal cycler (MJ Research, Waltham, MA). Polymerase chain reaction products were analyzed by gel electrophoresis in $2 \%$ agarose gels.

\section{MMUOC116 Positioning on the Physical Map}

We used two primer pairs (D19 Car333 and D19Car319) for the positioning of MMUOC116, as illustrated in Figure 3. Each pair corresponded, respectively, to the $5^{\prime}$ and to the $3^{\prime}$ end of the mouse gene, and upstream and downstream primers were as follows: D19Car333, 5'-TAGCTTGAAGCAGATTGTACG-3' and 5'-CTCAACTTCGGCTTAGGATC-3'; D19Car319, 5'CAGCTCTTTATTCCTGTCCC-3' and 5'-CTTCATGCACCAAGCAATCC-3'

\section{FISH}

BAC DNA was labeled using nick-translation with biotin-14dATP (Life Technologies). The labeled probe $(1 \mu \mathrm{g} / \mathrm{slide})$ was coprecipitated with $30 \mu \mathrm{g}$ of mouse Cot-1 DNA (Life Technologies), denatured for $5 \mathrm{~min}$ at $70^{\circ} \mathrm{C}$ in hybridization mixture (50\% formamide, $2 \times$ SSC, $10 \%$ Dextran sulfate), and reannealed for $30-60 \mathrm{~min}$ at $37^{\circ} \mathrm{C}$. The probe was then hybridized on denatured pretreated metaphase chromosomes from mouse SV22-CD cell line $e^{2}$ overnight in a moist chamber at $37^{\circ} \mathrm{C}$. The following steps were performed as described previously. ${ }^{8}$ 
(A)
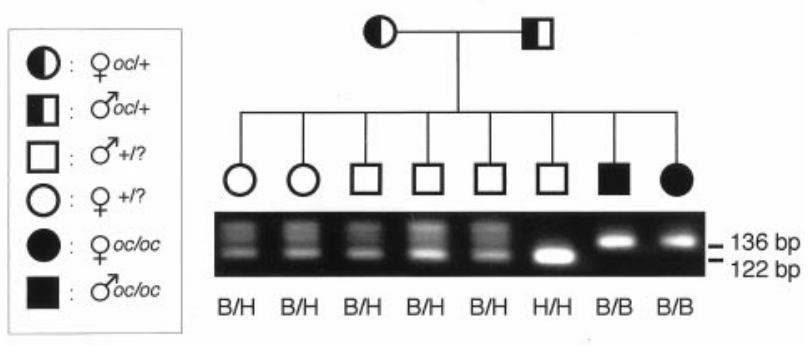

(B)

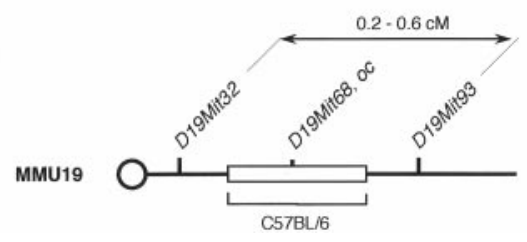

Figure 2. (A) Genotyping of an $o c /+\times o c /+$ cross with the polymorphic microsatellite D19Mit68. Mutant oc/oc mice show the cosegregation of the osteopetrotic phenotype with C57BL/6 alleles (B/B). (B) Schematic representation of the $\mathrm{C} 57 \mathrm{BL} / 6$ minimal region cosegregating with D19Mit68 and the oc locus. Recombinant $o c / o c$ and $o c /+$ animals excluded D19Mit32 and D19Mit93 as proximal and distal boundaries, respectively. The genetic distance between these two boundaries is derived from the EUCIB data.

\section{BAC Sequencing and Clone Assembly}

BAC DNA was prepared according to a standard alkaline lysis protocol, and purified twice on a $\mathrm{CsCl}$ gradient. BAC DNA (20 $\mu \mathrm{g}$ ) was mechanically disrupted using a hydroshear device (Gene Machines, San Carlos, CA), generating genomic DNA fragments an average of $3 \mathrm{~kb}$ in size. BAC DNA fragments were repaired with T4 DNA polymerase, and ligated to BstXI adaptors (Invitrogen, Groningen, The Netherlands). DNA adaptor-ligated fragments were purified by electrophoresis on a $0.7 \%$ agarose (FMC Bioproducts, Rockland, ME) preparative gel. After electrophoresis, fragments were excised from the gel, purified on Qiaquick columns (Qiagen, Courtaboef, France), and ligated to pcDNA2.1 vector (Invitrogen). Recombinant plasmids were transformed into Escherichia coli DH10B cells by electroporation (Electromax; Life Technologies). Ampicillin-resistant bacterial clones were picked with a Flexy robot (Proteigene, Saint-Marcel, France) and inoculated in 96-well arrays. Clones corresponding to 12 96-well dishes ( $8 \times$ BAC length) were end-sequenced on a Licor 4200 system (Li-Cor Inc., Lincoln, NE). Sequence assembly was performed using the Phred-Phrap software. ${ }^{7}$

\section{Genomic DNA Amplification and Sequencing}

Genomic DNA (50-100 ng) (prepared from mouse tail) was used as a matrix for amplification with the following upstream and downstream primers: 5'-ATCCTAAGCCGAAGTTGAGC-3' and 5'-TCCGTTTCCTCCTGGATGC-3'. Polymerase chain reaction products were purified using the High Pure PCR product purification kit (Roche Diagnostics, Meylan, France). After sequencing with IRD700-labeled reverse primer (MWG Biotech, Ebersberg, Germany), the analysis was performed as described above.

\section{Reverse Transcription (RT)-PCR}

We extracted total RNA from kidney with Extract All reagent (Eurobio, Les Ulis, France), and cDNA was generated using Expand reverse transcriptase (Roche) and $\mathrm{p}(\mathrm{dT})_{15}$ oligonucleotide (Roche) in a $40-\mu \mathrm{L}$ reaction volume under conditions recommended by the manufacturer. Polymerase chain reaction was performed with the following upstream and downstream primers: 5'-ATCCTAAGCCGAAGTTGAGC-3' and 5'-TCCGTTTCCTCCTGGATGC-3'. Polymerase chain reaction products were purified using the High Pure PCR product purification kit, and subcloned into pGEMT-Easy vector (Promega) according to the manufacturer's protocol. Recombinant plasmids were transformed into JM109 competent bacteria. Plasmid DNAs were prepared using the Wizard Plus SV miniprep kit (Promega, Charbonnieres, France), digested with Not I (two sites flanking the cloning site of the vector), and analyzed by gel electrophoresis in $2 \%$ agarose gel. After sequencing of plasmid DNAs with IRD700-labeled SP6 and M13u (universal) primers (MWG), the analysis was performed as described above. The GenBank accession number is AF188702.

\section{Results}

\section{Genetic Mapping of the oc Mutation}

In the present study, we have been able to refine the genetic localization of the $o c$ gene in the pericentromeric region of mouse chromosome 19 using an interspecific intercross of the type: (B6C3-a/a F1 oc/ $+\times$ Mus spretus $) \mathrm{F} 1 o c /+\times(\mathrm{B} 6 \mathrm{C} 3-a / a$ $\mathrm{F} 1 o c /+\times$ Mus spretus) $\mathrm{F} 1 o c /+$. Close to $400 \mathrm{~F} 2$ progeny were generated, and using eight microsatellite markers (D19Mit22, D19Mit31, D19Mit32, D19Mit42, D19Mit51, D19Mit68, D19Mit93, and D19Mit109), polymorphic between C57BL/6, $\mathrm{C} 3 \mathrm{H}$, and Mus spretus, $24+/$ ? recombinants and $20 \mathrm{oc} / \mathrm{oc}$ recombinant animals were typed in more details (data not shown). Backcrossing the original mutant stock to B6C3-a/a F1 hybrids ${ }^{17}$ in order to generate vigourous breeding stock introduced a $\mathrm{C} 3 \mathrm{H}$ genetic background that was detected on MMU19 in heterozygotes $o c /+$ mice.

The analysis of these recombinants led to the definition of a minimal candidate region, with D19Mit32 representing the centromeric boundary and D19Mit93 the telomeric one. High-resolution genetic maps of mouse chromosomes have been generated in the European Collaborative Interspecific Mouse Backcross (EUCIB) project based on close to a thousand progeny produced by an interspecific backcross between C57BL/6 and Mus spretus. $^{6}$ In that project, the genetic distance between D19Mit32 and D19Mit93 ranges from 0.2 to $0.6 \mathrm{cM}$ in the BSS and BSB crosses, respectively (http://www.informatics.jax.org/menus/ map_menu.shtml).

Finally, the systematic genotyping of over $200 \mathrm{oc} / \mathrm{oc}$ mice generated from the (B6C3-a/a F1 oc/+) $\times(\mathrm{B} 6 \mathrm{C} 3-a / a \mathrm{~F} 1 o c /+)$ cross showed, invariably, $\mathrm{B} / \mathrm{B}$ homozygous alleles for D19Mit68 segregating with the osteopetrotic phenotype (an example of the pedigree is shown in Figure 2). Thus, a defined region bearing the C57BL/6 background in which the $o c$ mutation appeared could be delimited by D19Mit32 and D19Mit93 and centered on D19Mit68.

\section{Physical Mapping of the Candidate Region}

Based on our genetic mapping results, a screening of YAC and BAC libraries was undertaken. From a first set of two YACs and three BACs, end probes were isolated and sequenced in order to derive new STS markers and build up a set of overlapping clones. 


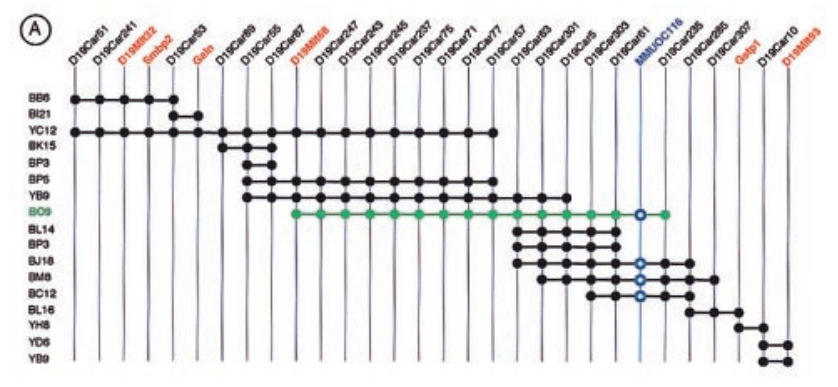

(B)

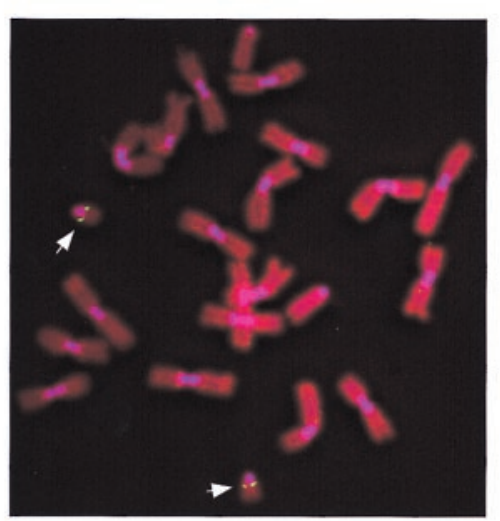

Figure 3. (A) BAC and YAC STS-based content contig map of the candidate region for the $o c$ locus. Bxx and Yxx represent BAC and YAC references, respectively. Positive PCR assays with each genomic clone are represented by a dot. Open circles identify PCR assays corresponding to MMUOC116. (B) FISH hybridization on SV22CD mouse metaphase chromosomes using the $\mathrm{BO} 9 \mathrm{BAC}$ DNA as a probe.

A more in-depth study of the physical map of this region of the mouse genome will be published separately (manuscript in preparation). Five YACs and 12 BACs were finally retained for further characterization and were assembled in an STS contentbased contig shown in Figure 3A. To ascertain the localization of the YAC and BAC genomic clones at the same time as testing for chimerism, fluorescent in situ hybridization was systematically performed on mouse SV22-CD metaphase chromosomes; an example of such hybridization using BAC BO9 DNA as a probe is shown in Figure 3B. Aside from the three microsatellite MIT markers, D19Mit32, D19Mit68, and D19Mit93, three genes conserved between HSA11q13 and MMU19 were positioned on this contig (Gstp1, Smbp2, and Galn). Twenty-one new STSs were generated from sequence data obtained either from BAC/YAC clone insert-end or internal sequencing. Oligonucleotide sequences for these PCR assays as well as the annealing temperature and the size of the product generated from a C57BL/6 DNA template are presented in Table 1. Five of these new STSs, present on BACs BP5 and/or BO9, display polymorphic PCR products between C57BL/6 and Mus spretus, which appeared to cosegregate with oc/oc animals like D19Mit68 (data not shown). We then generated a 1.1-Mb contig based on a set of overlapping $\mathrm{BAC} / \mathrm{YAC}$ clones including both proximal and distal boundaries of the candidate region where $o c$ had been located.

\section{A Mouse Homologue of the Human 116-kDa V-ATPase Subunit Gene (MMUOC116) Is Mutated in oc/oc Mice}

The physical and genetic mapping results guided our choice in the selection of two BACs of $120 \mathrm{~kb}$ (BP5) and $220 \mathrm{~kb}$ (BO9) for shotgun cloning and sequencing. Sequence comparison using BLAST-based software ${ }^{1}$ between one of the contigs of BAC BO9 against several database (nr GenBank, dbEST, dbSTS, ... ) identified five mouse ESTs (GenBank Accession Nos. AI663350, AI549720, AI180721, AI649394, AI607442) displaying sequence identity with one sequence contig of the BO9 clone. This set of ESTs showed a high degree of similarity to the cDNA sequence of a new human osteoclast-specific 116-kDa vacuolar proton pump subunit (OC-116KDa) (Genbank Accession No. U45285). ${ }^{15}$ Based on the sequence of these five mouse ESTs, we
Figure 4. DNA sequence comparison of mouse OC116 gene in wt and in oc/oc mice. (a) The distal border of the deletion (exon 3 into intron1) in normal $(+/+)$ and mutant $(o c / o c)$ genomic DNA. (b) The expected exon $1 /$ exon 2 junction in $+/+$ mice cDNA, and one of the alternative RT-PCR products derived from $o c / o c$ mice. (c) A schematic representation of the 1.6-kb deletion in genomic DNA present in oc/oc mutants compared with the wild type.
Scimeca J-C, et al.

a)

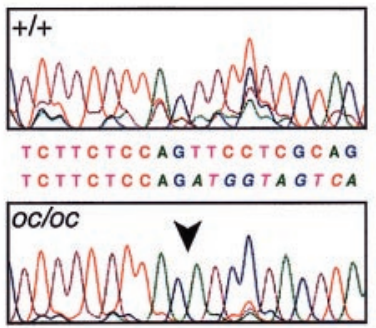

c)

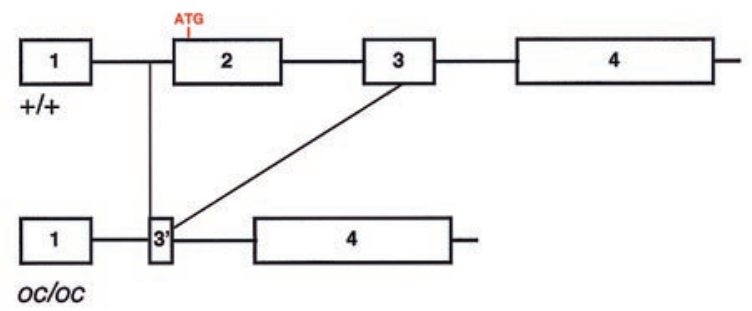

b)
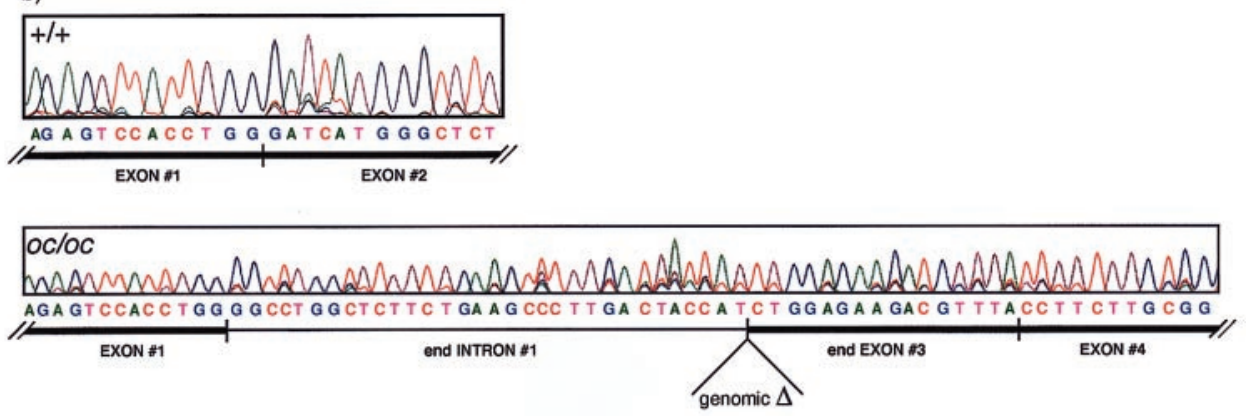


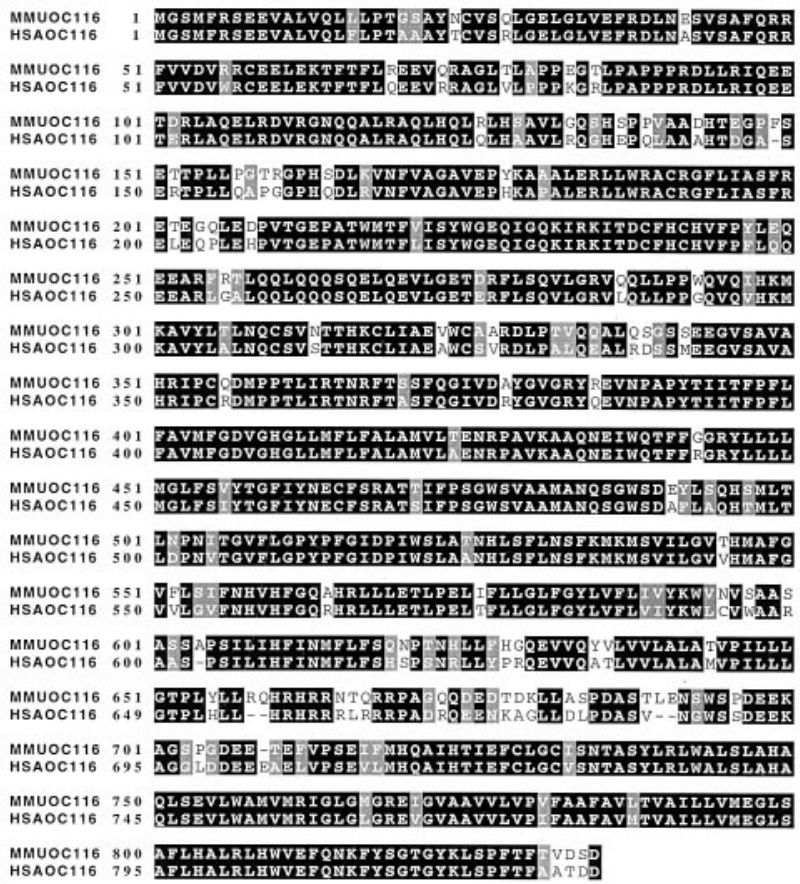

Figure 5. Amino acid comparison of mouse vs. human OC116 predicted protein sequences. Black boxes represent identical residues, while grey boxes correspond to similar ones.

designed oligonucleotide primers to perform RT-PCR experiments on mRNAs derived from kidneys of wt and oc/oc mice.

A set of primers chosen between exon 1 and exon 4 of OC116 revealed a major size difference between the RT-PCR products generated from wt or mutant mice (data not shown). While the corresponding bands of these RT-PCR products were gel purified, cloned, and sequenced, genomic sequencing was performed on DNA extracted from wt and $o c / o c$ mice. A 1579-bp deletion starting in the middle of intron 1 and extending 62 bp into exon 3 was identified in the genomic DNA of oc/oc mice (Figure $4 a, c)$. This deletion removes the translation start site present at the beginning of exon 2. The sequence analysis of RT-PCR products derived from $o c / o c$ mice showed either exon 1/exon 4 junctions (data not shown) or an alternative splice site in intron 1, 32 bp upstream from the 1579-bp genomic deletion (Figure $4 \mathrm{~b})$. Thus, while RT-PCR products between exon 1 and 4 are accurately spliced in kidneys of wt mice, a large genomic deletion removing exon 2 and most of exon 3 results in aberrant mRNA transcripts in mutant animals.

The predicted protein encoded by the mouse homologue of OC116 displays $84 \%$ identities and $91 \%$ similitudes at the amino acid level with its human homologue (Figure 5). A recent study by Heinemann et al. ${ }^{12}$ localized the OC116 gene at $11 \mathrm{q} 13$ by fluorescent in situ hybridization on human metaphase chromosomes and described the genomic organization of this gene. Based on these results and the sequence data of the five mouse ESTs described previously, we were able to predict the intron/ exon structure of MMUOC116. Similarly to what was found by Heinemann et al., we identified 20 exons ranging from $79 \mathrm{bp}$ (exons 1 and 3) up to 221 bp (exon 4). The translation start site is also present in exon 2, and the UAG stop codon is in exon 20. Thus, based on the MMUOC116 gene location and the high similarity of amino acid sequence with human OC116-predicted protein, it is very likely that the gene we isolated, as being mutated in oc/oc mice, is the mouse homologue of the human OC116 gene.

\section{Discussion}

We have isolated the mouse homologue of a new human osteoclast-specific vacuolar proton pump subunit gene that appears to be deleted over $1.6 \mathrm{~kb}$ at its $5^{\prime}$ end in osteosclerosis (oc/oc) mutants. This result was achieved by a positional cloning strategy starting from the segregation of the $o c$ mutation in an interspecific genetic cross to define proximal and distal recombination boundaries, followed by physical mapping over several hundreds of kilobases, and finishing by the sequence of a 200-kb genomic area.

The human OC116 gene was isolated by $\mathrm{Li}$ et al. and reported as putative novel human osteoclast-specific vacuolar proton pump subunit. ${ }^{15}$ We hypothesize that the $1.6-\mathrm{kb}$ deletion present in $o c / o c$ mice inactivates the normal expression of the MMUOC116 gene and, consequently, could be deleterious for the vacuolar proton pump localization and expression on apical membranes of osteoclast cells. Indeed, previous work by Nakamura et al. ${ }^{18}$ demonstrated that although the vacuolar $\mathrm{H}^{+}$ATPase proton pump was still active in oc/oc mice and present throughout the cytoplasm, it was no longer found on the osteoclast apical membranes. One of the features of oc/oc mice osteoclasts is the absence of ruffled border formation, leading to a defect in bone resorption. Whether the mislocalization of the vacuolar proton pump to the outer membrane of osteoclasts is a cause or a consequence of this lack of ruffling remains to be discovered.

Recently, Heaney et al. described the mapping of human autosomal recessive osteopetrosis to a 14-cM interval on $11 \mathrm{q} 13 .{ }^{11}$ This rare form of human osteopetrosis is lethal within the first decade in the absence of bone marrow transplantation, ${ }^{9,10}$ and its phenotype presents many similarities with the osteosclerosis mutation. Based on the present work, it is very likely that mutations affecting OC116 gene expression could be responsible for this form of human osteopetrosis. Sequencing of the entire OC116 genomic sequence of such affected individuals is presently in progress in our laboratory.

Finally, Li et al have recently presented an abstract at the $21 \mathrm{st}$ American Society for Bone and Mineral Research Meeting, showing that knockout $-/-$ mice for the OC116 gene were growth retarded, developed severe osteopetrosis with deficiencies in bone remodeling and tooth eruption, and died at about 4 weeks of age. ${ }^{16}$ All these phenotypic features are highly similar to what has been described for oc/oc mice, and strongly suggest that the genomic DNA deletion we observed in the MMUOC116 gene is sufficient to account for this phenotype.

Acknowledgments: The authors thank Jean-Marc Gaillochon, Gilles Gaudray, Jean-Noël Charrier, and José Barbe for technical assitance; and are very grateful to Philip Avner, Jean-Louis Guénet, and Jean Weissenbach for their support. This work was funded by grants from the Ministère de la Recherche (GREG N59/94), the Association pour la Recherche contre le Cancer, and the GIP-Hoechst Marion Roussel (\#FR/98BON005).

\section{References}

1. Altschul, S. F., Madden, T. L., Schaffer, A. A., Zhang, J., Zhang, Z., Miller, W., and Lipman, D. J. Gapped BLAST and PSI-BLAST: a new generation of protein database search programs. Nucleic Acids Res 25:3389-3402; 1997.

2. Baron, B., Metezeau, P., Kelly, F., Bernheim, A., Berger, R., Guenet, J. L., and Goldberg, M. E. Flow cytometry isolation and improved visualization of sorted 
mouse chromosomes. Purification of chromosomes X and ISO-1 from cell lines with Robertsonian translocations. Exp Cell Res 152:220-230; 1984.

3. Brady, K. P., Dushkin, H., Fornzler, D., Koike, T., Magner, F., Her, H., Gullans, S., Segre, G. V., Green, R. M., and Beier, D. R. A novel putative transporter maps to the osteosclerosis (oc) mutation and is not expressed in the oc mutant mouse. Genomics 56:254-261; 1999.

4. Courseaux, A., Szepetowski, P., Fernandes, M., Serizet, C., Kawaguchi, Y., Grosgeorge, J., Perucca-Lostanlen, D., Shows, T. B., Todd, J. A., Nowak, N. J., and Gaudray, P. Framework YAC contig anchored into a 3.2-Mb highresolution physical map in proximal 11q13. Genomics 40:13-23; 1997.

5. Dickie, M. M. Private communication. Mouse News Letter 36:39; 1967.

6. European Backcross Collaborative Group. Towards high resolution maps of the mouse and human genomes: a facility for ordering markers to $0.1 \mathrm{cM}$ resolution. Hum Mol Genet 3:621-627; 1994.

7. Ewing, B., Hillier, L., Wendl, M. C., and Green, P. Base-calling of automated sequencer traces using phred. I. Accuracy assessment. Genome Res 8:175-185; 1998.

8. Fernandes, M., Lespinasse, F., Rotomondo, F., Poirier, C., Guenet, J. L., Gaudray, P., and Carle, G. F. Comparative mapping of two adjacent regions of MMU19 with their human counterpart on HSA11q13. Cytogenet Cell Genet 81:237-246; 1998

9. Fischer, A., Griscelli, C., Friedrich, W., Kubanek, B., Levinsky, R., Morgan, G., Vossen, J., Wagemaker, G., and Landais, P. Bone-marrow transplantation for immunodeficiencies and osteopetrosis: European survey, 1968-1985. Lancet $2: 1080-1084 ; 1986$.

10. Gerritsen, E. J., Vossen, J. M., van Loo, I. H., Hermans, J., Helfrich, M. H., Griscelli, C., and Fischer, A. Autosomal recessive osteopetrosis: variability of findings at diagnosis and during the natural course. Pediatrics 93:247-253; 1994.

11. Heaney, C., Shalev, H., Elbedour, K., Carmi, R., Staack, J. B., Sheffield, V. C., and Beier, D. R. Human autosomal recessive osteopetrosis maps to $11 \mathrm{q} 13$, a position predicted by comparative mapping of the murine osteosclerosis (oc) mutation. Hum Mol Genet 7:1407-1410; 1998.

12. Heinemann, T., Bulwin, G. C., Randall, J., Schnieders, B., Sandhoff, K., Volk, H. D., Milford, E., Gullans, S. R., and Utku, N. Genomic organization of the gene coding for TIRC7, a novel membrane protein essential for $\mathrm{T}$ cell activation. Genomics 57:398-406; 1999.

13. Hodgkinson, C. A., Moore, K. J., Nakayama, A., Steingrimsson, E., Copeland,
N. G., Jenkins, N. A., and Arnheiter, H. Mutations at the mouse microphthalmia locus are associated with defects in a gene encoding a novel basic-helixloop-helix-zipper protein. Cell 74:395-404; 1993.

14. Lane, P. W. Private communication. Mouse News Letter 52:37; 1975.

15. Li, Y. P., Chen, W., and Stashenko, P. Molecular cloning and characterization of a putative novel human osteoclast-specific 116-kDa vacuolar proton pump subunit. Biochem Biophys Res Commun 218:813-821; 1996.

16. Li, Y. P., Chen, W., and Stashenko, P. 21st Annual Meeting of the American Society for Bone and Mineral Research. St. Louis, MO, September 30 to October 4, 1999. Abstracts. J Bone Miner Res 14(Suppl. 1):S177; 1999.

17. Marks, S. C., Jr., Seifert, M. F., and Lane, P. W. Osteosclerosis, a recessive skeletal mutation on chromosome 19 in the mouse. J Hered 76:171-176; 1985.

18. Nakamura, I., Takahashi, N., Udagawa, N., Moriyama, Y., Kurokawa, T., Jimi, E., Sasaki, T., and Suda, T. Lack of vacuolar proton ATPase association with the cytoskeleton in osteoclasts of osteosclerotic (oc/oc) mice. FEBS Lett 401:207-212; 1997.

19. Schreiber, M., Poirier, C., Franchi, A., Kurzbauer, R., Guenet, J. L., Carle, G. F., and Wagner, E. F. Structure and chromosomal assignment of the mouse fra-1 gene, and its exclusion as a candidate gene for oc (osteosclerosis). Oncogene 15:1171-1178; 1997.

20. Stewart, C., Parente, F., Piehl, F., Farnebo, F., Quincey, D., Silins, G. Bergman, L., Carle, G. F., Lemmens, I., Grimmond, S., Xian, C. Z., Khodei, S., Teh, B. T., Lagercrantz, J., Siggers, P., Calender, A., Van de Vem, V., Kas, K., Weber, G., Hayward, N., Gaudray, P., and Larsson, C. Characterization of the mouse Men1 gene and its expression during development. Oncogene 17:24852493; 1998.

21. Szepetowski, P. and Gaudray, P. FCER1B, a candidate gene for atopy, is located in 11q13 between CD20 and TCN1. Genomics 19:399-400; 1994.

22. Yoshida, H., Hayashi, S., Kunisada, T., Ogawa, M., Nishikawa, S., Okamura, H., Sudo, T., and Shultz, L. D. The murine mutation osteopetrosis is in the coding region of the macrophage colony stimulating factor gene. Nature 345:442-444; 1990.
Date Received: November 1, 1999 Date Revised: December 6, 1999 Date Accepted: December 6, 1999 